\title{
Clinical practice of image-guided spine radiosurgery - results from an international research consortium
}

\author{
Matthias Guckenberger ${ }^{1 *}$, Reinhart A Sweeney ${ }^{1}$, John C Flickinger ${ }^{2,3}$, Peter C Gerszten ${ }^{2,4}$, Ronald Kersh ${ }^{5,6}$, \\ Jason Sheehan ${ }^{7}$ and Arjun Sahgal ${ }^{8}$
}

\begin{abstract}
Background: Spinal radiosurgery is a quickly evolving technique in the radiotherapy and neurosurgical communities. However, the methods of spine radiosurgery have not been standardized. This article describes the results of a survey about the methods of spine radiosurgery at five international institutions.

Methods: All institutions are members of the Elekta Spine Radiosurgery Research Consortium and have a dedicated research and clinical focus on image-guided radiosurgery. The questionnaire consisted of 75 items covering all major steps of spine radiosurgery.

Results: Strong agreement in the methods of spine radiosurgery was observed. In particular, similarities were observed with safety and quality assurance playing an important role in the methods of all institutions, cooperation between neurosurgeons and radiation oncologists in case selection, dedicated imaging for target- and organ-at-risk delineation, application of proper safety margins for the target volume and organs-at-risk, conformal planning and precise image-guided treatment delivery, and close clinical and radiological follow-up. In contrast, three major areas of uncertainty and disagreement were identified: 1) Indications and contra-indications for spine radiosurgery; 2) treatment dose and fractionation and 3) tolerance dose of the spinal cord.

Conclusions: Results of this study reflect the current practice of spine radiosurgery in large academic centers. Despite close agreement was observed in many steps of spine radiosurgery, further research in form of retrospective and especially prospective studies is required to refine the details of spinal radiosurgery in terms of safety and efficacy.
\end{abstract}

Keywords: vertebral metastases, spine radiosurgery, methods, questionnaire

\section{Background}

Radiotherapy is a well-established treatment for painful vertebral metastases. Multiple prospective studies report pain response rates of 50 to $90 \%$ [1-4]. Based on randomized studies, no differences in pain response have been observed between the various fractionation schemes that range from 40 Gy in 20 fractions to 8 Gy in a single fraction $[5,6]$.

Despite the lack of a dose response relationship for pain control, there is good rationale for high dose

\footnotetext{
* Correspondence: Guckenberger_M@klinik.uni-wuerzburg.de 'Department of Radiation Oncology, University Hospital Wuerzburg, Wuerzburg, Germany

Full list of author information is available at the end of the article
}

escalation beyond those conventional dose levels tested with the aim to improve upon existing rates of local and pain control. The median duration of pain response after conventional palliative radiotherapy is approximately 3 to 6 months, again without differences between the different fractionation schemes [1-4]. Only short palliation after conventional radiotherapy seems to be the case especially for unfavorable histologies (lung, kidney, head \& neck and gastrointestinal cancer, melanoma, sarcoma) as observed in a randomized trial for metastatic spinal cord compression [7]. This brief palliative effect may be sufficient for some patients with very short life expectancy. However, several predictive scores have been reported, which allow selection of patients with

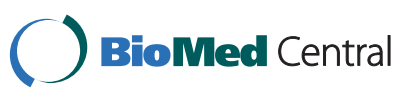


long life expectancy [8-10]. In particular, as modern chemotherapy may further prolong life expectancy, long-term palliation and long-term tumor control become even more important goals for patients despite having metastatic disease.

As a consequence, there is currently large interest in intensification of radiotherapy for painful vertebral metastases. A recent survey from the Unites States reported that $64 \%$ of the radiation oncologists practice stereotactic body radiotherapy (SBRT) and treatment of vertebral metastases was the second most common disease site (67.5\% of all SBRT users) [11]. Spine SBRT was practiced most frequently as single fraction radiosurgery with doses of $20 \mathrm{~Gy}$ or $18 \mathrm{~Gy}$. The most frequently cited reasons for practice of SBRT were the possibility of dose-intensified treatment and re-irradiation. In the remainder of this manuscript, we will use the term radiosurgery for both single-fraction and multiple-fraction SBRT as the techniques of the entire treatment processes are identical between both.

Multiple retrospective and few prospective studies have reported promising results for spine radiosurgery with low rates of toxicity and pain control as well as local tumor control rates consistently ranging between $70-90 \%$ [12-18]. Importantly, the risk of permanent spinal cord damage secondary to radiation induced myelopathy has been reported as very low. Despite these promising data, recent reviews have pointed out the lack of uniformity in practice [19-21], and currently the community has no standard approach to the practice of spine radiosurgery. For example, there is variability in the treatment techniques, the total dose prescribed to the tumor, number of fractions, criteria for plan acceptance and the dose limits used to the organs at risk. One recent advance in providing guidance and uniformity to the practice of spine radiosurgery has been the RTOG phase II/III trial that is currently accruing in the US (RTOG 0631); however, results of this trial will not be available in the near future.

The purpose of our study is to give a broad and comprehensive overview of the current methods of spine radiosurgery by surveying experienced practitioners. Five institutions, all members of the international Elekta Spine Radiosurgery Research Consortium, answered a questionnaire with detailed questions about all steps of spine radiosurgery from indication to follow-up. All centers used identical equipment for treatment delivery (Elekta Synergy $S$ linacs all equipped with cone-beam and robotic HexaPOD technology), which facilitates methods comparison between the institutions.

\section{Methods}

The Elekta Spine Radiosurgery Research Consortium (ESRRC) is an international research consortium consisting of five institutions, all of them with a research and clinical focus on image-guided high precision radiotherapy in general and spine radiosurgery in particular. Four of five institutions are academic hospitals (University Hospital Wuerzburg [UHW], Wuerzburg, Germany; Princess Margaret Hospital (PMH) and the Sunnybrook Health Sciences Center (SHSC) of the University of Toronto [UofT], Toronto, Canada; University of Pittsburgh Medical Center [UPMC], Pittsburgh, US; University of Virginia Medical Center [UVAMC], Charlottesville, US) and one is a private radiotherapy center fully specialized in image-guided radiosurgery (Riverside Regional Medical Center [RSMC], Newport News, US). All institutions have treated more than 50 patients with vertebral metastases using image-guided radiosurgery and all academic centers have contributed to the recent technical and clinical progress in spine SBRT.

Each center uses identical equipment for delivery of spine radiosurgery: treatment is planned for a high-resolution multi-leaf collimator with $4 \mathrm{~mm}$ leaf width (Beam modulator on Elekta Synergy S linear accelerator; Elekta, Crawley, UK), daily volumetric image-guidance is performed with cone-beam technology (Elekta XVI, Crawley, UK), set-up errors are corrected in six degrees of freedom (HexaPOD; Medical Intelligence, Schwabmuenchen) and all patients are immobilized in the BodyFIX system (Medical Intelligence, Schwabmuenchen, Germany).

A questionnaire with 75 items was established covering all major aspects of spine radiosurgery including: indications for spine radiosurgery, imaging required for treatment planning, target and organ-at-risk (OAR) definition, treatment planning, dose and fractionation, tolerance doses for OARs, patient positioning and imageguidance, follow-up and response evaluation. Re-irradiation and post-operative radiosurgery was not evaluated in this questionnaire. The questionnaires were answered by the responsible physician from each institution and reflect their current practice of spinal radiosurgery.

\section{Results}

\section{Indication for spine radiosurgery}

Rationales for the practice of spine radiosurgery compared to conventional palliative radiotherapy are similar between the five institutions: all agree on more durable pain control and long-term local tumor control. Four institutions state a more rapid pain relief as reason for spine radiosurgery (UPMC, UofT, UVAMC, RSMC), three institutions explicitly mention spine radiosurgery for radio-resistant histologies (UHW, UVAMC, UofT), two institutions use spine radiosurgery because of better patient convenience (UPMC, RSMC) and one institution describes the potential of improved overall survival in the oligometastatic setting as reason for spine radiosurgery (UHW). Radiosensitive histologies are excluded in 
Table 1 Patient specific factors influencing indication for spine SBRT

\begin{tabular}{|c|c|c|c|c|c|}
\hline & UHW & UPMC & UofT & UVAMC & RSMC \\
\hline $\begin{array}{l}\text { Use of a predictive } \\
\text { scoring system for OS }\end{array}$ & Yes, Mizumoto Score & No & $\begin{array}{c}\text { Life expectancy } \geq 3 \\
\text { months }\end{array}$ & $\begin{array}{c}\text { Patients with widespread } \\
\text { CNS and systemic disease } \\
\text { are excluded }\end{array}$ & No \\
\hline $\begin{array}{l}\text { Histology of primary } \\
\text { tumor }\end{array}$ & $\begin{array}{l}\text { No treatment of } \\
\text { highly radiosensitive } \\
\text { histologies }\end{array}$ & $\begin{array}{l}\text { Avoid relatively } \\
\text { radiosensitive histologies }\end{array}$ & $\begin{array}{l}\text { No myeloma unless } \\
\text { previously radiated }\end{array}$ & $\begin{array}{l}\text { No treatment of } \\
\text { radiosensitive histologies }\end{array}$ & $\begin{array}{l}\text { No relevant } \\
\text { factor }\end{array}$ \\
\hline Status of primary tumor & $\begin{array}{l}\text { Yes, part of the } \\
\text { Mizumoto Score }\end{array}$ & No relevant factor & $\begin{array}{l}\text { Yes, for estimation of } \\
\text { life expectancy }\end{array}$ & No relevant factor & $\begin{array}{l}\text { No relevant } \\
\text { factor }\end{array}$ \\
\hline $\begin{array}{l}\text { Presence of visceral } \\
\text { metastases }\end{array}$ & $\begin{array}{l}\text { Yes, part of the } \\
\text { Mizumoto Score }\end{array}$ & No relevant factor & $\begin{array}{l}\text { Yes, for estimation of } \\
\text { life expectancy }\end{array}$ & Yes, see above & $\begin{array}{l}\text { No relevant } \\
\text { factor }\end{array}$ \\
\hline$\overline{\text { Age }}$ & $\begin{array}{l}\text { Yes, part of the } \\
\text { Mizumoto Score }\end{array}$ & No relevant factor & No relevant factor & No relevant factor & $\begin{array}{l}\text { No relevant } \\
\text { factor }\end{array}$ \\
\hline $\begin{array}{l}\text { Performance status of } \\
\text { patient }\end{array}$ & $\begin{array}{l}\text { Yes, part of the } \\
\text { Mizumoto Score }\end{array}$ & $\begin{array}{c}\text { Exclusion of patients with } \\
\text { extremely poor } \\
\text { performance status }\end{array}$ & $\begin{array}{l}\text { Must be able to } \\
\text { tolerate } \\
\text { immobilization for } 45 \\
\text { min. }\end{array}$ & KPS should be $\geq 70$ & $\begin{array}{c}\text { KPS must be } \\
\geq 60\end{array}$ \\
\hline $\begin{array}{l}\text { Comorbidities of } \\
\text { patient }\end{array}$ & No relevant factor & No relevant factor & No relevant factor & No relevant factor & $\begin{array}{l}\text { No relevant } \\
\text { factor }\end{array}$ \\
\hline $\begin{array}{l}\text { Interval between } \\
\text { primary tumor and } \\
\text { spinal metastases }\end{array}$ & No relevant factor & No relevant factor & No relevant factor & No relevant factor & $\begin{array}{l}\text { No relevant } \\
\text { factor }\end{array}$ \\
\hline
\end{tabular}

all but one (RSMC) institution and a minimum performance status is required in all institutions (table 1). All four academic centers perform spine radiosurgery in the framework of a prospective protocol but not as a prospective trial.

In contrast, patient selection with respect to estimated live expectancy is substantially different: one institution strictly selects patients with good life expectancy using a predictive scoring system for overall survival (UHW), two centers exclude patients with very poor life expectancy (UofT, UVAMC) and life expectancy is no relevant factor for two institutions (UPMC, RSMC).

\section{Characteristics of metastatic lesions treated with spine radiosurgery}

The inclusion and exclusion criteria of vertebral metastasis treated with spine radiosurgery are described in table 2. There is agreement that the relationship between the target volume and any OAR other than the spinal cord does not influence the indication for spine radiosurgery. Both lytic and sclerotic lesions are treated and all institutions but one (UHW) prefer a stabilization procedure prior to radiosurgery in cases of spinal instability. Compression fractures are always discussed with the neurosurgeon/spine surgeon and symptomatic spinal cord compression is a contraindication in all institutions. All vertebras in the cervical, thoracic and lumbar spine are treated and the number of vertebras within one target volume is limited to 3 except one institution, were only two vertebras are allowed within one target volume (RSMC).
Disagreement is evident whether epidural involvement or a small distance between the metastasis and the spinal cord are contraindications.

\section{Imaging for staging and target definition}

There is a good agreement in the imaging modalities and their technical application for staging and target definition (table 3). All institutions acquire dedicated CT and MRI images (a diagnostic MRI is allowed at the UPMC) for delineation and slice thickness is between 1-2 mm.

Differences, however, are observed in the MRI sequences and in acquisition of a dedicated planning FDG-PET.

\section{Target and OAR definition}

Similar target volume concepts are used in the five institutions (table 4). All centers define the gross-tumor volume (GTV) based on CT and MR imaging, two centers perform co-registration of a FDG-PET (UPMC, RSMC). All centers treat the involved vertebras only without "prophylactic" irradiation of the superior and inferior vertebra. All institutions use an anatomical target volume concept where the target volume extends to uninvolved parts of the vertebras. Additionally, all institutions but one (RSMC) apply safety margins of 2-3 mm.

However, the details of the target volume concepts are different. Three institutions do always treated the entire vertebral body and/or the entire posterior elements in case of involvement (UPMC, UVAMC, RSMC). One institution has a similar concept, however, differentiates between the ipsilateral and contralateral posterior 
Table 2 Target specific factors influencing indication for spine SBRT

\begin{tabular}{|c|c|c|c|c|c|}
\hline & UHW & UPMC & UofT & UVAMC & RSMC \\
\hline $\begin{array}{l}\text { Location of } \\
\text { vertebral } \\
\text { metastases (C, } \\
T, L)\end{array}$ & No relevant factor & No relevant factor & $\begin{array}{l}\text { No relevant } \\
\text { factor }\end{array}$ & No relevant factor & No relevant factor \\
\hline $\begin{array}{l}\text { Number of } \\
\text { vertebras in } \\
\text { one target } \\
\text { volume }\end{array}$ & Maximum of 3 levels & Maximum of 3 levels & $\begin{array}{l}\text { Maximum of } 3 \\
\text { levels }\end{array}$ & Maximum of 3 levels & Maximum of 2 levels \\
\hline $\begin{array}{l}\text { Extent of } \\
\text { vertebral } \\
\text { metastases }\end{array}$ & $\begin{array}{l}\text { Symptomatic and } \\
\text { progressive cord } \\
\text { compression is } \\
\text { contraindication. }\end{array}$ & $\begin{array}{c}\text { Significant spinal cord } \\
\text { compression associated with } \\
\text { myelopathy is } \\
\text { contraindication. }\end{array}$ & $\begin{array}{l}\text { Symptomatic } \\
\text { cord } \\
\text { compression is } \\
\text { contraindication. }\end{array}$ & $\begin{array}{l}\text { Symptomatic cord compression } \\
\text { is contraindication. }\end{array}$ & $\begin{array}{l}\text { Symptomatic cord } \\
\text { compression is } \\
\text { contraindication. }\end{array}$ \\
\hline $\begin{array}{l}\text { Epidural } \\
\text { involvement }\end{array}$ & No relevant factor & No relevant factor & $\begin{array}{l}\text { Surgery if high } \\
\text { grade epidural } \\
\text { involvement } \\
\text { present }\end{array}$ & $\begin{array}{l}\text { Minimum of } 2 \mathrm{~mm} \text { of clearance } \\
\text { between the gross metastastic } \\
\text { disease and the spinal cord }\end{array}$ & No relevant factor \\
\hline $\begin{array}{l}\text { Stability of } \\
\text { metastatic } \\
\text { vertebra }\end{array}$ & $\begin{array}{l}\text { Surgical opinion sought } \\
\text { first }\end{array}$ & $\begin{array}{l}\text { Instability is preferably } \\
\text { treated with stabilization } \\
\text { procedure }\end{array}$ & $\begin{array}{l}\text { Surgical opinion } \\
\text { sought first }\end{array}$ & $\begin{array}{l}\text { Instability is preferably treated } \\
\text { with stabilization procedure }\end{array}$ & $\begin{array}{l}\text { Instability is } \\
\text { preferably treated } \\
\text { with stabilization } \\
\text { procedure }\end{array}$ \\
\hline $\begin{array}{l}\text { Lytic or } \\
\text { sclerotic } \\
\text { metastasis }\end{array}$ & No relevant factor & No relevant factor & $\begin{array}{l}\text { No relevant } \\
\text { factor }\end{array}$ & No relevant factor & No relevant factor \\
\hline $\begin{array}{l}\text { Vertebral } \\
\text { compression } \\
\text { fracture }\end{array}$ & $\begin{array}{c}\text { Symptomatic } \\
\text { compression fracture } \\
\text { are discussed with } \\
\text { neurosurgeons in } \\
\text { advance }\end{array}$ & $\begin{array}{l}\text { Compression fracture } \\
\text { causing kyphosis and pain } \\
\text { will be treated BEFORE } \\
\text { radiosurgery if possible }\end{array}$ & $\begin{array}{l}\text { Surgical opinion } \\
\text { sought first }\end{array}$ & $\begin{array}{c}\text { Compression fracture causing } \\
\text { marked kyphosis or instability } \\
\text { will be treated with stabilization } \\
\text { procedure first }\end{array}$ & $\begin{array}{c}\text { Compression fracture } \\
\text { is preferably treated } \\
\text { with stabilization } \\
\text { procedure }\end{array}$ \\
\hline $\begin{array}{l}\text { Location of } \\
\text { metastasis } \\
\text { relative to other } \\
\text { organs at risk }\end{array}$ & No relevant factor & No relevant factor & $\begin{array}{l}\text { No relevant } \\
\text { factor }\end{array}$ & No relevant factor & No relevant factor \\
\hline
\end{tabular}

elements (UofT). One institution uses a two dose level approach where the high-dose target volume is defined as the GTV with a $3 \mathrm{~mm}$ safety margin and the lowdose target volume is the entire vertebra (UHW).

Regarding definition of the OAR spinal cord, all but one institution (RSMC) define the spinal cord in the MRI images; the spinal canal is delineated in CT images at the RSMC. Delineation is performed minimum 1 vertebra superior and inferior to the planning target volume (PTV) in all institutions and safety margins of 1-2 $\mathrm{mm}$ are applied for generation of the planning OAR spinal cord in all but one institution (UVAMC). On the level of the cauda equina, all institutions define the thecal sac as planning OAR.

\section{Treatment dose and fractionation}

Large variability is observed in terms of treatment dose and fractionation (tables 5). Two institutions treat the

Table 3 Imaging for staging \& target definition

\begin{tabular}{|c|c|c|c|c|c|}
\hline & UHW & UPMC & UofT & UVAMC & RSMC \\
\hline $\begin{array}{l}\text { Staging examinations prior to } \\
\text { SBRT/SRS }\end{array}$ & $\begin{array}{l}\text { Oncologic staging is } \\
\text { required }\end{array}$ & None & MRI spine & None & None \\
\hline Slice thickness of Planning $C T$ & $1.5 \mathrm{~mm}$ & $1.25 \mathrm{~mm}$ & $1 \mathrm{~mm}$ & 1 to $1.5 \mathrm{~mm}$ & $2 \mathrm{~mm}$ \\
\hline MRI used for target definition & Yes & Yes & Yes & Yes & Yes \\
\hline Dedicated Planning MRI & Yes & No & Yes & Yes & Yes \\
\hline Slice thickness of planning MRI & $2 \mathrm{~mm}$ & $1.25 \mathrm{~mm}$ & $1 \mathrm{~mm}$ & $1.2 \mathrm{~mm}$ & $\begin{array}{c}3 \mathrm{~mm} / 1.25 \\
\mathrm{~mm}\end{array}$ \\
\hline $\begin{array}{l}\text { MRI sequence used for target } \\
\text { definition, }\end{array}$ & $\begin{array}{l}\text { T1 with and w/o } \\
\text { contrast; } \mathrm{T} 2\end{array}$ & $\begin{array}{c}\text { T1 with } \\
\text { contrast; T2 }\end{array}$ & $\begin{array}{c}\text { T1 w/o contrast volumetric VIBE; T2 } \\
\text { volumetric SPACE }\end{array}$ & $\begin{array}{l}\text { T1 with contrast volume } \\
\text { acquisition }\end{array}$ & $\begin{array}{l}\text { T1 with } \\
\text { and w/o }\end{array}$ \\
\hline $\begin{array}{l}\text { Dedicated FDG-PET/PET-CT for } \\
\text { target definition }\end{array}$ & Rarely & Yes & No & Rarely & Yes \\
\hline
\end{tabular}


Table 4 Target and organs-at-risk definition

\begin{tabular}{|c|c|c|c|c|c|}
\hline & UHW & UPMC & UofT & UVAMC & RSMC \\
\hline $\begin{array}{l}\text { Imaging modality, } \\
\text { which is used for GTV } \\
\text { definition }\end{array}$ & $\mathrm{MRI}$ and $\mathrm{CT}$ & $\begin{array}{l}\text { MRI and CT, FDG- } \\
\text { PET if available }\end{array}$ & $\mathrm{MRI}$ and $\mathrm{CT}$ & $\mathrm{CT}$ and $\mathrm{MRI}$ & $\begin{array}{l}C T, M R I \text { and } \\
\text { FDG-PET }\end{array}$ \\
\hline $\begin{array}{l}\text { Use of an anatomical } \\
\text { target volume concept }\end{array}$ & $\begin{array}{c}\text { Anatomical two dose-level target } \\
\text { volume concept }\end{array}$ & $\begin{array}{l}\text { Anatomical target } \\
\text { volume concept }\end{array}$ & $\begin{array}{l}\text { Anatomical target } \\
\text { volume concept }\end{array}$ & $\begin{array}{l}\text { Anatomical target volume } \\
\text { concept }\end{array}$ & $\begin{array}{c}\text { Anatomical } \\
\text { target } \\
\text { volume } \\
\text { concept }\end{array}$ \\
\hline $\begin{array}{l}\text { GTV to PTV safety } \\
\text { margin }\end{array}$ & $3 \mathrm{~mm}$ & $\begin{array}{c}2 \mathrm{~mm} ; 3 \mathrm{~mm} \text { in the } \\
\text { sacrum. }\end{array}$ & $2 \mathrm{~mm}$ & $2 \mathrm{~mm}$ & None \\
\hline $\begin{array}{l}\text { Protocol if PTV overlaps } \\
\text { with the. spinal cord }\end{array}$ & $\begin{array}{c}\text { Two dose-level approach; } \\
\text { The OAR spinal cord is always in the } \\
\text { PTV-elective and is always excluded } \\
\text { from the higher dose PTV- } \\
\text { macroscopic }\end{array}$ & $\begin{array}{l}\text { PTV within } 1 \mathrm{~mm} \text { to } \\
\text { the spinal cord is } \\
\text { excluded from the } \\
\text { PTV }\end{array}$ & $\begin{array}{l}\text { PTV is limited by } \\
\text { the cord or thecal } \\
\text { sac for cauda } \\
\text { equina }\end{array}$ & $\begin{array}{l}\text { If this occurs, we either } \\
\text { operate to resect part of the } \\
\text { tumor or fractionate the } \\
\text { radiation. }\end{array}$ & $\begin{array}{l}\text { GTV drawn } \\
\text { to edge of } \\
\text { OAR }\end{array}$ \\
\hline $\begin{array}{l}\text { Treatment of the } \\
\text { vertebra superior and } \\
\text { inferior to the } \\
\text { metastatic vertebra }\end{array}$ & No & No & No & No & No \\
\hline $\begin{array}{l}\text { Imaging modality for } \\
\text { definition of the spinal } \\
\text { cord }\end{array}$ & Spinal cord in MRI & Spinal cord in MRI & Spinal cord in MRI & Spinal cord in MRI & $\begin{array}{l}\text { Spinal canal } \\
\quad \text { in } C T\end{array}$ \\
\hline $\begin{array}{l}\text { Delineation of the } \\
\text { spinal cord in cranio- } \\
\text { caudal direction }\end{array}$ & $\begin{array}{c}\text { At least } 1 \text { level above and below } \\
\text { PTV }\end{array}$ & $\begin{array}{l}1 \text { level above and } \\
\text { below PTV }\end{array}$ & $\begin{array}{c}\text { At least } 1 \text { level } \\
\text { above and below } \\
\text { PTV }\end{array}$ & $\begin{array}{c}1 \text { level above and below } \\
\text { PTV }\end{array}$ & $\begin{array}{l}1 \text { level } \\
\text { above and } \\
\text { below PTV }\end{array}$ \\
\hline $\begin{array}{l}\text { Safety margins around } \\
\text { the spinal cord in axial } \\
\text { directions }\end{array}$ & $1 \mathrm{~mm}$ & $1 \mathrm{~mm}$ & $1.5 \mathrm{~mm}$ & No & $\begin{array}{c}2 \mathrm{~mm} \\
\text { anterior } \\
\text { and } 1 \mathrm{~mm} \\
\text { lateral }\end{array}$ \\
\hline $\begin{array}{l}\text { Delineation of the } \\
\text { cauda equina }\end{array}$ & Thecal sac & Thecal sac & Thecal sac & Thecal sac & Thecal sac \\
\hline $\begin{array}{l}\text { Delineation other OARs } \\
\text { (e.g. kidney) }\end{array}$ & No application of safety margins & $\begin{array}{l}\text { No application of } \\
\text { safety margins }\end{array}$ & $\begin{array}{l}\text { No application of } \\
\text { safety margins }\end{array}$ & $\begin{array}{l}\text { No application of safety } \\
\text { margins }\end{array}$ & $\begin{array}{l}\text { No } \\
\text { application } \\
\text { of safety } \\
\text { margins }\end{array}$ \\
\hline
\end{tabular}

majority of their patients with single fraction radiosurgery of 16 - 24 Gy (UPMC, UVAMC). One center prefers 2 or 3 fraction radiosurgery (UofT), however, will treat with single fraction if no epidural disease is evident and single level disease. Two centers perform fractionated radiosurgery only (UHW, RSMC), and both of them choose between two fractionation schemas with estimated life expectancy as selection criterion. Fractionated radiosurgery is performed in 2-10 fractions with physical doses of 24-48.5 Gy. Despite the differences in dose and fractionation, all but one institution practice dose prescription to the D90, whereas one institution uses the ICRU reference point (UofT).

Based on an $\alpha / \beta=10 \mathrm{~Gy}$, the median 2 Gy-equivalent dose $\left(\mathrm{EQD}_{2} \mathrm{~Gy}\right)$ is $50 \mathrm{~Gy}$ [minimum $36 \mathrm{~Gy}(3 \times 8 \mathrm{~Gy})$ and maximum 68 Gy $(1 \times 24$ Gy $)]$. As described above, one institution (UHW) uses a two dose-level concept with conventional doses in the "elective" parts of the vertebra $(10 \times 3$ Gy; $5 \times 4$ Gy $)$ and dose escalated irradiation in the involved parts of the vertebra $(10 \times 4.85$ Gy; $5 \times 7$ Gy).

\section{Spinal cord tolerance doses}

No institution varies the spinal cord tolerance based on cervical, thoracic or lumbar target location. Otherwise, dosimetric parameters as well as tolerance doses for the spinal cord and thecal sac were substantially different between all five institutions (table 6).

\section{Treatment planning}

Minor differences are observed in terms of treatment planning (table 7). All institutions treat their patients at an Elekta Synergy S linear accelerator equipped with the Beam Modulator (4 mm leaf width); one center does also perform spine radiosurgery on different linear accelerators (UVAMC). Treatment planning system is Pinnacle (Philips Radiation Oncology Systems, Milpitas, CA, USA) and intensity modulation is planed using step-and-shoot IMRT only (UPMC), both IMRT and VMAT (UHW, RSMC, UofT) and VMAT only (UVAMC). Technical details are summarized in table 7.

Acceptance criteria for treatment plans vary substantially with all centers stating that no strict criteria exist, 
Table 5 Doses and fractionation

\begin{tabular}{|c|c|c|c|c|c|}
\hline & UHW & UPMC & UofT & UVAMC & RSMC \\
\hline $\begin{array}{l}\text { Use of single } \\
\text { fraction } \\
\text { radiosurgery }\end{array}$ & $\begin{array}{l}\text { No, all patients are } \\
\text { treated with either five or } \\
\text { ten fractions }\end{array}$ & $\begin{array}{l}\text { Single fraction } \\
\text { radiosurgery for } 95 \% \text { of } \\
\text { the patients unless very } \\
\text { near to spinal cord. }\end{array}$ & $\begin{array}{l}\text { Majority is treated with } \\
\text { two or three fractions } \\
\text { and specific cases for } \\
\text { single fraction }\end{array}$ & $\begin{array}{l}\text { Majority is treated with a } \\
\text { single fraction of } \\
\text { radiosurgery, occasionally } \\
\text { up to } 3 \text { fractions }\end{array}$ & $\begin{array}{c}\text { No, majority are treated } \\
\text { with three fractions with } \\
\text { treatments given one } \\
\text { week apart. }\end{array}$ \\
\hline $\begin{array}{l}\text { Criteria for } \\
\text { selection of } \\
\text { hypo- } \\
\text { fractionated } \\
\text { regimes }\end{array}$ & $\begin{array}{l}\text { Selection of fractionation } \\
\text { scheme based on life } \\
\text { expectancy using the } \\
\text { Mizumoto Score }\end{array}$ & & $\begin{array}{l}\text { Fractionated protocols } \\
\text { in: } \\
\text { 1. Epidural disease or } \\
\text { large volume and no } \\
\text { prior irradiation } \\
\text { 2. Prior radiation }\end{array}$ & $\begin{array}{l}\text { Fractionated protocols } \\
\text { after prior radiation }\end{array}$ & $\begin{array}{l}\text { If it represents the only } \\
\text { site of disease, we use } \\
30 \text { Gy in } 3\end{array}$ \\
\hline $\begin{array}{l}\text { Schema 1: \# } \\
\text { fractions and } \\
\text { single fraction } \\
\text { dose }\end{array}$ & $\begin{array}{l}\text { Good life expectancy: } \\
30 \text { Gy in 10: PTV-elective } \\
48.5 \text { Gy in 10: PTV } \\
\text {-macroscopic * }\end{array}$ & $\begin{array}{c}16-24 \text { Gy in } 1 ; \\
\text { Most frequently } 17 \text { Gy in } \\
1\end{array}$ & $\begin{array}{l}20-24 \text { Gy in } 1 ; \\
\text { Most frequently } 20 \text { Gy } \\
\text { in } 1\end{array}$ & $\begin{array}{l}18 \text { to } 24 \text { Gy in } 1 ; \\
\text { Most frequently } 20 \text { Gy in } \\
1\end{array}$ & 24 Gy in 3 \\
\hline $\begin{array}{l}\text { Schema 2: \# } \\
\text { fractions and } \\
\text { single fraction } \\
\text { dose }\end{array}$ & $\begin{array}{c}\text { Intermediate life } \\
\text { expectancy: } \\
20 \text { Gy in 5: PTV-elective } \\
35 \text { Gy in 5: PTV } \\
\text {-macroscopic * }\end{array}$ & & $24-27$ Gy in $2-3$ & $24 \mathrm{~Gy}$ in 3 & 30 Gy in 3 \\
\hline $\begin{array}{l}\text { Schema 3: \# } \\
\text { fractions and } \\
\text { single fraction } \\
\text { dose }\end{array}$ & & & $\begin{array}{c}30 \text { Gy in } 3 \\
\text { (for sarcomas) }\end{array}$ & 18 Gy in 3 & \\
\hline $\begin{array}{l}\text { Dose } \\
\text { prescription }\end{array}$ & D90 & D90 & ICRU point & D90 & D90 \\
\hline
\end{tabular}

* a simultaneous integrated boost (SIB) was used at the UHW with two dose levels to PTV -macroscopic and PTV -elective

mostly because of the large variability of the target volumes in terms of size, shape and distance to the spinal cord and other relevant OARs. However, all institutions agree that PTV coverage is sacrificed until the dose limits of the critical OARs, especially of the spinal cord, are fulfilled.

Patient positioning, immobilization and image-guidance Differences in these steps of spine radiosurgery are small (table 8). All patients are treated in supine position and immobilization is performed using thermoplastic head masks for cervical/upper thoracic lesions and the BodyFIX for thoracic and lumbar lesions. Daily pre-treatment image guidance is performed using cone-beam technology and set-up errors are corrected in six degrees of freedom using the robotic HexaPOD couch. Action level for translational errors is $1 \mathrm{~mm}$ in all but one institution where a larger action level of $2 \mathrm{~mm}$ is used (UVAMC); the action level for rotational errors is $1^{\circ}$ in four institutions (UHW, UPMC, UofT, UVAMC), $0.3^{\circ}$ in one

Table 6 Spinal cord tolerance doses

\begin{tabular}{|c|c|c|c|c|c|}
\hline & \multirow[b]{2}{*}{ Dosimetric parameter } & \multicolumn{4}{|c|}{ Tolerance doses Spinal Cord } \\
\hline & & Single fraction & 3 fractions & 5 fractions & 10 fractions \\
\hline UHW & Dmax to $0.1 \mathrm{cc}$ & & & $23.75 \mathrm{~Gy}$ & 35 Gy \\
\hline UPMC & Dmax & $11 \mathrm{~Gy}$ & $18 \mathrm{~Gy}$ & & \\
\hline UofT & Dmax & 10 Gy & $17.5 \mathrm{~Gy}$ & $22 \mathrm{~Gy}$ & \\
\hline UVAMC & D10 & $10 \mathrm{~Gy}$ & 15 Gy & 20 Gy & \\
\hline \multirow[t]{3}{*}{$\mathrm{RSMC}$} & $2 c c$ & & 18 Gy & & \\
\hline & & \multicolumn{4}{|c|}{ Tolerance doses Cauda equina } \\
\hline & Dosimetric parameter & Single fraction & 3 fractions & 5 fractions & 10 fractions \\
\hline UHW & Dmax to $0.1 \mathrm{cc}$ & & & 25 Gy & 37.5 Gy \\
\hline UPMC & Dmax & 12 Gy & $18 \mathrm{~Gy}$ & & \\
\hline UofT & Dmax & 12 Gy & $18 \mathrm{~Gy}$ & 23 Gy & \\
\hline UVAMC & D10 & $12 \mathrm{~Gy}$ & 15 Gy & $20 \mathrm{~Gy}$ & \\
\hline $\mathrm{RSMC}$ & $2 c c$ & & $24 \mathrm{~Gy}$ & & \\
\hline
\end{tabular}


Table 7 Treatment planning

\begin{tabular}{|c|c|c|c|c|c|}
\hline & UHW & UPMC & UofT & UVAMC & RSMC \\
\hline Treatment planning system & Pinnacle & Pinnacle & Pinnacle & $\begin{array}{c}\text { Varian Eclipse, } \\
\text { Tomotherapy, } \\
\text { Pinnacle for Elekta }\end{array}$ & $\begin{array}{l}\text { 1. Elekta/CMS XiO, } \\
\text { 2. Elekta/CMS Monaco }\end{array}$ \\
\hline Linac model/MLC leaf width & Elekta Synergy S/4 mm & Synergy $\mathrm{S} / 4 \mathrm{~mm}$ & $\begin{array}{l}\text { Elekta Synergy S/ } \\
\quad 4 \mathrm{~mm}\end{array}$ & $\begin{array}{c}\text { Elekta Synergy S, } \\
\text { Varian Triliogy, } \\
\text { Tomotherapy }\end{array}$ & Elekta Synergy S/4 mm \\
\hline $\begin{array}{l}\text { IMRT or VMAT treatment } \\
\text { planning }\end{array}$ & Both & IMRT & Both & VMAT & Both \\
\hline $\begin{array}{l}\text { If step-and-shoot IMRT: } \\
\text { number of beams }\end{array}$ & 9 beams on average & $\begin{array}{l}9 \text { to } 14, \text { but most } \\
\text { are } 12 \text { beams }\end{array}$ & $9-11$ beams & 10 beams & 10 beams \\
\hline If VMAT: number of arcs & $1-2$ arcs & Not applicable & 1 arc & $1-3$ arcs & $\begin{array}{l}\text { 1. one arc } 120-140 \text { segments } \\
\text { 2. VMAT - } 4 \text { arcs - 30-40 } \\
\text { segments per arc }\end{array}$ \\
\hline Full or partial VMAT arc & 360 degrees & 360 degrees & 360 degrees & 360 degree $\operatorname{arcs}$ & $\begin{array}{l}\text { 1. VMAT } 350 \text { deg arc } \\
\text { 2. VMAT posteriorly biased } \\
\text { arcs, } 2 \text { couch kicks }\end{array}$ \\
\hline Photon energy & $\begin{array}{c}6 \text { or } 10 \mathrm{mV} \text { depending } \\
\text { on location }\end{array}$ & $6 \mathrm{MV}$ & $6 \mathrm{MV}$ & $6 \mathrm{MV}$ & $6 \mathrm{MV}$ \\
\hline $\begin{array}{l}\text { Dosimetric parameters for } \\
\text { plan acceptance }\end{array}$ & $\begin{array}{c}\text { No strict acceptance } \\
\text { criteria. }\end{array}$ & Usually V90 & $\begin{array}{l}\text { CTV V80 of at } \\
\text { least } 80-90 \%\end{array}$ & $\begin{array}{c}\text { No strict } \\
\text { acceptance criteria }\end{array}$ & Generally D90 \\
\hline
\end{tabular}

institution (RSMC). A second cone-beam CT scan for verification of the IGRT shift is performed in all institutions and all institutions but one (UHW) perform intratreatment cone-beam CT scanning for patient monitoring. A final scan after treatment delivery is performed in 3/5 institutions (UHW, UofT, UVAMC).

\section{Follow-up}

Follow up is performed in-house whenever possible in all institutions; the interval is most frequently every 3 months (table 9). Local tumor control is defined as tumor shrinkage or no tumor progression in serial imaging, with MRI as the preferable imaging modality. One

\section{Table 8 Patient (re-)positioning and IGRT}

\begin{tabular}{|c|c|c|c|c|c|}
\hline & UHW & UPMC & UofT & UVAMC & RSMC \\
\hline $\begin{array}{l}\text { Treatment prone or } \\
\text { supine }\end{array}$ & Supine & Supine & Supine & supine & Supine \\
\hline Immobilization device & $\begin{array}{c}\text { Cervical: } \\
\text { Thermoplastic } \\
\text { mask; } \\
\text { Otherwise } \\
\text { BodyFIX }\end{array}$ & $\begin{array}{l}\text { Cervical down to T5: } \\
\text { aquaplast face mask; } \\
\text { otherwise BodyFIX }\end{array}$ & $\begin{array}{l}\text { Cervical down to } \\
\text { T2/3 s frame; } \\
\text { otherwise BodyFIX }\end{array}$ & $\begin{array}{c}\text { Cervical: Thermoplastic } \\
\text { mask; } \\
\text { otherwise BodyFIX }\end{array}$ & $\begin{array}{l}\text { Cervical: Aquaplast mask with } \\
\text { Accuform support secured to } \\
\text { modified S-frame; } \\
\text { otherwise BodyFIX }\end{array}$ \\
\hline $\begin{array}{l}\text { Image guidance } \\
\text { technology }\end{array}$ & $\begin{array}{c}\text { Cone-beam } \\
\text { CT }\end{array}$ & Cone-beam CT & Cone-beam CT & Cone-beam CT & Cone-beam CT \\
\hline Frequency of IGRT & Daily & Daily & Daily & Daily & Daily \\
\hline $\begin{array}{l}\text { Correction of } \\
\text { rotational set-up errors }\end{array}$ & $\begin{array}{l}\text { Yes - Hexapod } \\
\text { couch }\end{array}$ & Yes - Hexapod couch & $\begin{array}{l}\text { Yes - Hexapod } \\
\text { couch }\end{array}$ & Yes - Hexapod couch & Yes - Hexapod couch \\
\hline $\begin{array}{l}\text { Action level for } \\
\text { correction of set-up } \\
\text { errors }\end{array}$ & $\begin{array}{l}1 \mathrm{~mm} \\
\text { translation, } \\
1 \text { degree } \\
\text { rotation }\end{array}$ & $\begin{array}{l}1 \text { mm translation, } \\
1 \text { degree rotation }\end{array}$ & $\begin{array}{l}1 \text { mm translation, } \\
1 \text { degree rotation }\end{array}$ & $\begin{array}{l}2 \mathrm{~mm} \text { translation, } \\
1 \text { degree rotation }\end{array}$ & $\begin{array}{l}1 \mathrm{~mm} \text { translation, } \\
0.3 \text { degree rotation }\end{array}$ \\
\hline $\begin{array}{l}\text { Second imaging after } \\
\text { couch adjustment } \\
\text { prior to treatment }\end{array}$ & Yes & Yes & Yes & Yes & Yes \\
\hline $\begin{array}{l}\text { Methods for intra- } \\
\text { fractional patient } \\
\text { monitoring }\end{array}$ & None & $\begin{array}{l}\text { Cone-beam CT imaging } \\
\text { after one and two thirds } \\
\text { through the treatment }\end{array}$ & $\begin{array}{l}\text { One to two intra- } \\
\text { treatment Cone- } \\
\text { beam CT scans }\end{array}$ & $\begin{array}{l}\text { One intra-fraction cone- } \\
\text { beam CT scan half-way } \\
\text { through treatment }\end{array}$ & $\begin{array}{l}\text { Typical one or two mid } \\
\text { treatment cone-beam CTs }\end{array}$ \\
\hline $\begin{array}{l}\text { Imaging after } \\
\text { treatment }\end{array}$ & Yes & No & Yes & Yes & No \\
\hline
\end{tabular}


Table 9 Follow-up and response evaluation

\begin{tabular}{|c|c|c|c|c|c|}
\hline & UHW & UPMC & UofT & UVAMC & RSMC \\
\hline Place of follow-up & In clinic & In clinic & In clinic & In clinic & In clinic \\
\hline Definition of local control & $\begin{array}{l}\text { No progression on serial } \\
\text { imaging. }\end{array}$ & $\begin{array}{c}\text { No progression on serial } \\
\text { imaging. }\end{array}$ & $\begin{array}{c}\text { No progression on serial } \\
\text { imaging. }\end{array}$ & $\begin{array}{l}\text { No progression } \\
\text { on serial } \\
\text { imaging. }\end{array}$ & $\begin{array}{l}\text { No progression } \\
\text { on serial } \\
\text { imaging. }\end{array}$ \\
\hline $\begin{array}{l}\text { Imaging modalities required } \\
\text { for definition of local control } \\
\end{array}$ & MRI if possible & MRI if possible & MRI if possible & MRI if possible & MRI/PET \\
\hline System for pain scoring & Visual analogue scale & Visual analogue scale & $\begin{array}{l}\text { N/A unless of study } \\
\text { then the Brief Pain } \\
\text { Inventory }\end{array}$ & $\begin{array}{l}\text { Visual analogue } \\
\text { scale }\end{array}$ & NRS-11 \\
\hline $\begin{array}{l}\text { Frequency of FU } \\
\text { examinations }\end{array}$ & $\begin{array}{c}\text { Every three months, } \\
\text { every six months after } 1 \\
\text { year }\end{array}$ & $\begin{array}{c}1 \text { month, then } 3 \text { months, } \\
\text { then } 6,12 \text {, and then } \\
\text { yearly. }\end{array}$ & Every 2-3 months & $\begin{array}{l}3 \text { month } \\
\text { intervals for the } \\
\text { first year }\end{array}$ & Every 3 months \\
\hline
\end{tabular}

institution (RSMC) uses routine FDG-PET imaging for evaluation of local tumor control. Pain is assessed in 4/5 institutions using either the Visual Analog Scale (UHW, UPMC, UVAMC) or NRS-11 (RSMC).

\section{Discussion}

This survey observed strong agreement in terms of the treatment planning and treatment delivery aspects of spine radiosurgery. Especially safety and quality assurance of this novel treatment technique play a major role in the methods of all institutions. The following measures are considered as highly important for as safe-aspossible practice of spine radiosurgery. 1) Close cooperation between radiation oncologists and neurosurgeons especially in patients with epidural disease, spinal cord compression and instability; 2) Limitation of the target volume to maximum 3 vertebras; 3) Dedicated imaging protocols for target and organ-at-risk definition; 4) Anatomical target volume concepts with application of proper safety margins for the target volume and the spinal cord; 5) Highly conformal treatment planning, daily image-guidance, thorough patient immobilization and intra-fraction patient monitoring; 6) Close followup with repeated clinical and radiological response evaluation.

In contrast, three major areas of uncertainty and disagreement were identified: 1) Indications and contraindications for spine radiosurgery; 2) treatment dose and 3) tolerance dose of the spinal cord. These areas will be discussed more in detail.

\section{Discussion with respect to Indication}

\section{Patient factors influencing indication for spine radiosurgery} Several prognostic scoring systems have been developed for overall survival after conventional, palliative radiotherapy for painful spine metastases $[8,10,22]$ or metastatic spinal cord compression [23]. Recently, a recursive partitioning analysis (RPA) was reported for survival specific to spine SBRT [24]. The most favorable patients
(Class 1, median OS of 21.1 months) were those with a time from primary diagnosis (TPD) $>30$ months and a Karnofsky performance status (KPS) $>70$, Class 2 was defined as those with a TPD $>30$ months and KPS $<70$ or a TPD $<30$ months and age $<70$ years (median OS of 8.7 months), and Class 3 was associated with the poorest outcomes and defined as TPD $<30$ months and age $>70$ years (median OS of 2.4 months). One could argue that spine radiosurgery would seem well indicated in patients with a longer life expectancy given that pain response of conventional doses is typically limited to 3 6 months (median duration of pain response) and multiple studies reported excellent pain control for a duration of 12 months after radiosurgery [12,13,25-27].

On the other hand, patients with short life expectancy could also benefit from spine radiosurgery; however, the rationale for radiosurgery would then be achievement of more rapid pain relief. For conventional radiotherapy, a mean pain response time of 3 weeks was reported by Van Der Linden et al. [28]. Ryu et al. and Chang et al. reported a slightly shorter median time to maximum pain relief of about 2 weeks such that even RPA class 3 patients could benefit from spine radiosurgery [12,25]. Whether this difference in pain relief reaches statistical significance needs to be demonstrated by a prospective trial. Until then, spine radiosurgery should be considered as a viable if not preferable option when rapid pain relief is required.

Tumor factors influencing indication for spine radiosurgery Radiosurgical treatment of patients with epidural involvement is a major point of controversy. For tree institutions, epidural involvement was not a relevant factor in the decision making process for spine radiosurgery, whereas two institutions either required a clearance margin between the GTV and the spinal cord or preferred a surgical procedure prior to radiosurgery. Of note, the RTOG 0631 trial mandates a margin of $5 \mathrm{~mm}$ between the GTV and the spinal cord. This variation in indication is most likely explained by the risk of 
recurrence at the epidural space: three studies reported that $47-50 \%$ of all local failures after spine radiosurgery occur at the epidural space $[12,27,29]$. Sahgal et al. reported a trend towards local tumor recurrence if the GTV was within a distance of $\leq 1 \mathrm{~mm}$ to the spinal cord [30] and the minimum dose delivered to the target volume was shown as correlated with local tumor control [31].

A strategy to cope with epidural disease could be the application of fractionation schemes, which are adapted to the extent of epidural involvement [32]: single-fraction radiosurgery for targets with a clearance margin between the tumor and the spinal cord and fractionated radiosurgery if this clearance margin is violated. This fractionation could make use of basic radiobiology and deliver higher biological effective doses to the epidural tumor. However, the details regarding clearance margin and number of treatment fractions still have to be defined.

\section{Dose-fractionation}

As previously mentioned, no dose response has been established for conventional palliative radiotherapy with doses between 8 Gy in 1 fraction and 40 Gy in 20 fractions. One explanation could be that all tested doses are well below established thresholds from radical radiotherapy: e.g. even the "high dose" approach of 40 Gy in 20 fractions would result in tumor control of less than $5 \%$ for NSCLC [33]. This hypothesis is supported by three studies, which reported a significant dose response relationship for primary $[17,31]$ and re-irradiation [34] spine radiosurgery. The Memorial Sloan-Kettering Cancer Center (MSMCC) group reported excellent local control of $>95 \%$ for a prescription dose of 24 Gy and a minimum dose of > $15.1 \mathrm{~Gy}$; however, the results are based on a retrospective review of serially dose-escalated patients and require validation before conclusions can be drawn. For pain control as primary endpoint, Ryu et al. reported a lower prescription dose threshold of 14 Gy; this dose response was not statistically significant [25]. It is important to interpret all these treatment doses in the context of the target and OAR volumes, which were used in the specific trials. Clinical application of any dose specification without detailed knowledge and application of the respective target and OAR concept cannot be recommended.

Centers in this study use a large rage of fractionations between single fraction to 10 fractions. Moreover, even within the single fraction treatment, the applied doses range between 16 Gy to $24 \mathrm{~Gy}$. In the US, radiosurgery and stereotactic body radiotherapy are defined as treatment with maximum five fractions. In this study, one institution uses a 10 fraction approach, which does not fall under this definition. Nevertheless, we use the term radiosurgery even for this 10 fraction regimen because of two reasons: 1) the clinical and technical practice of the 10 fraction regimen is identical to the regimens using 1 - 5 fractions; 2) using the LQ model, the biological effective dose of the 10 fraction regimen is expected to be at least equivalent to the $1-5$ fractions regimens. However, the limitations of the LQ model need to be considered for very high single fraction doses [35].

\section{Tolerance dose of the spinal cord}

The third area of uncertainty and disagreement is the tolerance dose of the spinal cord. There was agreement between 4/5 institutions that a planning organ-at-risk should be generated with a safety margin around the true spinal cord. However, this safety margin varied between $1 \mathrm{~mm}$ around the spinal cord to $2 \mathrm{~mm}$ around the spinal canal. The dosimteric parameter used as dose threshold varied between $\mathrm{D}_{\max }, \mathrm{D} 10, \mathrm{D}_{0.1}$ cc and $\mathrm{D}_{2 \text { cc. }}$. The closest agreement was observed for single fraction radiosurgery, where dose thresholds of 10 - 11 Gy are used.

A very low incidence of myelopathy after spine radiosurgery has been described in the literature, despite dose escalation and hypo-fractionation. Ryu et al. observed a myelopathy in 1 out of 86 patients with a minimum follow-up of one year; these authors recommended a tolerance dose of $10 \mathrm{~Gy}$ as D10 [36]. Combined data from Stanford University Medical Center and University of Pittsburgh Medical Center reported an incidence of 5 out of 1075 patients, and it was recommended limiting the volume of spinal cord treated above an 8-Gy equivalent dose [37]. Sahgal et al. collected five cases of myelopathy and compared various dose volume parameters with 29 patients, who did not develop myelopathy [38]; all patients were treated with various radiosurgical fractionations. The thecal sack was delineated as the planning organ-at-risk volume for all cases and controls with centralized review of the DVH data. Doses were converted to 2 Gy-equivalent doses based on an $\alpha / \beta=2$ Gy to cope with variation of fractionation. The maximum point volume $\mathrm{EQD}_{2}$ Gy within the thecal sac significantly correlated with the risk of myelopathy as opposed to the larger volumes investigated $(0.1 \mathrm{cc}, 2 \mathrm{cc}$, and $5 \mathrm{cc})$. An $\mathrm{EQD}_{2}$ Gy threshold of 30 - 35 Gy was recommended for 1 - 5 fractions. In conventionally fractionated radiotherapy, the tolerance of the spinal cord is usually accepted between $45-50$ Gy, despite that even a dose of 60 Gy results in a risk of myelopathy of only approximately $5 \%$ [39]. This disagreement between $\mathrm{EQD}_{2}$ Gy thresholds based on hypofractionation and thresholds based on conventionally fractionated radiotherapy has recently been confirmed by Daly et al. [40]. Further research is consequently required in this field as we do not yet understand the 
biologic ramifications of high dose per fraction on the normal tissues or tumor itself.

\section{Conclusions}

Strong agreement in the methods of spine radiosurgery was observed. In particular, similarities were observed with safety and quality assurance playing an important role in the methods of all institutions: cooperation between neurosurgeons and radiation oncologists in case selection, dedicated imaging for target- and organat-risk delineation, application of proper safety margins for the target volume and organs-at-risk, conformal planning and precise image-guided treatment delivery, and close clinical and radiological follow-up. In contrast, three major areas of uncertainty and disagreement were identified: 1) Indications and contra-indications for spine radiosurgery; 2) treatment dose and fractionation and 3) tolerance dose of the spinal cord. Further research in form of retrospective and especially prospective studies is required to refine spinal radiosurgery in terms of safety and efficacy.

\section{Author details \\ 'Department of Radiation Oncology, University Hospital Wuerzburg, Wuerzburg, Germany. ${ }^{2}$ Department Radiation Oncology, University of Pittsburgh School of Medicine, Pittsburgh, Pennsylvania, USA. ${ }^{3}$ Center for Image-Guided Neurosurgery, University of Pittsburgh School of Medicine, Pittsburgh, Pennsylvania, USA. ${ }^{4}$ Department of Neurological Surgery, University of Pittsburgh School of Medicine, Pittsburgh, Pennsylvania, USA. ${ }^{5}$ Department of Radiation Oncology, University of Virginia, Charlottesville, Virginia, USA. ${ }^{6}$ Riverside Medical Center, Newport News, Virginia, USA. ${ }^{7}$ Department of Neurological Surgery, University of Virginia School of Medicine, Charlottesville, Virginia, USA. ${ }^{8}$ Dept. of Radiation Oncology, Princess Margaret Hospital, Toronto, Ontario, Canada.}

\section{Authors' contributions}

MG designed the study, collected the data and performed the data analysis. RAS participated in data collection and analysis. JCF, PDG, RK, JS, AS participated in data collection. All authors performed critical review of the manuscript and finally approved the manuscript.

\section{Competing interests}

This research was partially supported through an Elekta research grant with all institutions being members of the Elekta Spine Radiosurgery Research Consortium. This work and these data, however, are the intellectual property of the individual group members and their sponsoring institutions.

Received: 5 September 2011 Accepted: 15 December 2011 Published: 15 December 2011

\section{References}

1. Gaze MN, Kelly CG, Kerr GR, Cull A, Cowie VJ, Gregor A, Howard GC, Rodger A: Pain relief and quality of life following radiotherapy for bone metastases: a randomised trial of two fractionation schedules. Radiotherapy and oncology: journal of the European Society for Therapeutic Radiology and Oncology 1997, 45(2):109-116.

2. Price P, Hoskin PJ, Easton D, Austin D, Palmer SG, Yarnold JR: Prospective randomised trial of single and multifraction radiotherapy schedules in the treatment of painful bony metastases. Radiotherapy and oncology: journal of the European Society for Therapeutic Radiology and Oncology 1986, 6(4):247-255.

3. Roos DE, Turner SL, O'Brien PC, Smith JG, Spry NA, Burmeister BH, Hoskin PJ, Ball DL: Randomized trial of 8 Gy in 1 versus 20 Gy in 5 fractions of radiotherapy for neuropathic pain due to bone metastases (Trans-Tasman Radiation Oncology Group, TROG 96.05). Radiotherapy and oncology: journal of the European Society for Therapeutic Radiology and Oncology 2005, 75(1):54-63.

4. Steenland E, Leer JW, van Houwelingen H, Post WJ, van den Hout WB, Kievit J, de Haes H, Martijn H, Oei B, Vonk E, et al: The effect of a single fraction compared to multiple fractions on painful bone metastases: a global analysis of the Dutch Bone Metastasis Study. Radiotherapy and oncology: journal of the European Society for Therapeutic Radiology and Oncology 1999, 52(2):101-109.

5. Chow E, Harris K, Fan G, Tsao M, Sze WM: Palliative radiotherapy trials for bone metastases: a systematic review. Journal of clinical oncology: official journal of the American Society of Clinical Oncology 2007, 25(11):1423-1436.

6. Lutz S, Berk L, Chang E, Chow E, Hahn C, Hoskin P, Howell D, Konski A, Kachnic L, Lo S, et al: Palliative radiotherapy for bone metastases: an ASTRO evidence-based guideline. International journal of radiation oncology, biology, physics 2011, 79(4):965-976.

7. Maranzano E, Bellavita R, Rossi R, De Angelis V, Frattegiani A, Bagnoli R, Mignogna M, Beneventi S, Lupattelli M, Ponticelli $P$, et al: Short-course versus split-course radiotherapy in metastatic spinal cord compression: results of a phase III, randomized, multicenter trial. J Clin Oncol 2005, 23(15):3358-3365.

8. van der Linden YM, Dijkstra SP, Vonk EJ, Marijnen CA, Leer JW: Prediction of survival in patients with metastases in the spinal column: results based on a randomized trial of radiotherapy. Cancer 2005, 103(2):320-328.

9. Chow E, Abdolell M, Panzarella T, Harris K, Bezjak A, Warde P, Tannock I: Predictive model for survival in patients with advanced cancer. Journal of clinical oncology: official journal of the American Society of Clinical Oncology 2008, 26(36):5863-5869.

10. Mizumoto M, Harada H, Asakura H, Hashimoto T, Furutani K, Hashii H, Takagi T, Katagiri H, Takahashi M, Nishimura T: Prognostic factors and a scoring system for survival after radiotherapy for metastases to the spinal column: a review of 544 patients at Shizuoka Cancer Center Hospital. Cancer 2008, 113(10):2816-2822.

11. Pan H, Simpson DR, Mell LK, Mundt AJ, Lawson JD: A survey of stereotactic body radiotherapy use in the United States. Cancer 2011.

12. Chang EL, Shiu AS, Mendel E, Mathews LA, Mahajan A, Allen PK, Weinberg JS, Brown BW, Wang XS, Woo SY, et al: Phase I/II study of stereotactic body radiotherapy for spinal metastasis and its pattern of failure. J Neurosurg Spine 2007, 7(2):151-160.

13. Gerszten PC, Burton SA, Ozhasoglu C, Welch WC: Radiosurgery for spinal metastases: clinical experience in 500 cases from a single institution. Spine 2007, 32(2):193-199.

14. Guckenberger M, Goebel J, Wilbert J, Baier K, Richter A, Sweeney RA, Bratengeier K, Flentje M: Clinical outcome of dose-escalated imageguided radiotherapy for spinal metastases. Int $J$ Radiat Oncol Biol Phys 2009, 75(3):828-835.

15. Ryu S, Rock J, Rosenblum M, Kim JH: Patterns of failure after single-dose radiosurgery for spinal metastasis. Journal of neurosurgery 2004, 101(Suppl 3):402-405.

16. Sahgal A, Chou D, Ames C, Ma L, Chuang C, Lamborn K, Huang K, Chin CT, Weinstein P, Larson D: Proximity of Spinous/Paraspinous Radiosurgery Metastatic Targets to the Spinal Cord Versus Risk of Local Failure. International Journal of Radiation Oncology*Biology*Physics 2007, 69(3, Supplement 1):S243.

17. Yamada Y, Bilsky MH, Lovelock DM, Venkatraman ES, Toner S, Johnson J, Zatcky J, Zelefsky MJ, Fuks Z: High-dose, single-fraction image-guided intensity-modulated radiotherapy for metastatic spinal lesions. International journal of radiation oncology, biology, physics 2008, 71(2):484-490.

18. Gong Y, Wang J, Bai S, Jiang X, Xu F: Conventionally-fractionated imageguided intensity modulated radiotherapy (IG-IMRT): a safe and effective treatment for cancer spinal metastasis. Radiation oncology 2008, 3:11.

19. Sahgal A, Larson DA, Chang EL: Stereotactic body radiosurgery for spinal metastases: a critical review. Int J Radiat Oncol Biol Phys 2008, 71(3):652-665.

20. Gerszten PC, Mendel E, Yamada Y: Radiotherapy and radiosurgery for metastatic spine disease: what are the options, indications, and outcomes? Spine 2009, 34(22 Suppl):S78-92.

21. Sahgal A, Bilsky M, Chang EL, Ma L, Yamada Y, Rhines LD, Letourneau D, Foote M, Yu E, Larson DA, et al: Stereotactic body radiotherapy for spinal 
metastases: current status, with a focus on its application in the postoperative patient. Journal of neurosurgery Spine 2011, 14(2):151-166.

22. Mizumoto $M$, Harada $H$, Asakura $H$, Hashimoto T, Furutani $K$, Hashii $H$, Murata H, Takagi T, Katagiri H, Takahashi M, et al: Radiotherapy for patients with metastases to the spinal column: a review of 603 patients at Shizuoka Cancer Center Hospital. International journal of radiation oncology, biology, physics 2011, 79(1):208-213.

23. Rades D, Dunst J, Schild SE: The first score predicting overall survival in patients with metastatic spinal cord compression. Cancer 2008, 112(1):157-161.

24. Chao ST, Koyfman SA, Woody N, Angelov L, Soeder SL, Reddy CA, Rybicki LA, Djemil T, Suh JH: Recursive Partitioning Analysis Index is Predictive for Overall Survival in Patients Undergoing Spine Stereotactic Body Radiation Therapy for Spinal Metastases. International journal of radiation oncology, biology, physics 2011.

25. Ryu S, Jin R, Jin JY, Chen Q, Rock J, Anderson J, Movsas B: Pain control by image-guided radiosurgery for solitary spinal metastasis. J Pain Symptom Manage 2008, 35(3):292-298.

26. Gagnon GJ, Nasr NM, Liao JJ, Molzahn I, Marsh D, McRae D, Henderson FC Sr: Treatment of spinal tumors using cyberknife fractionated stereotactic radiosurgery: pain and quality-of-life assessment after treatment in 200 patients. Neurosurgery 2009, 64(2):297-306, discussion 306-297.

27. Nguyen QN, Shiu AS, Rhines LD, Wang H, Allen PK, Wang XS, Chang EL: Management of spinal metastases from renal cell carcinoma using stereotactic body radiotherapy. International journal of radiation oncology, biology, physics 2010, 76(4):1185-1192.

28. van der Linden YM, Lok JJ, Steenland E, Martijn $H$, van Houwelingen $H$, Marijnen CA, Leer JW: Single fraction radiotherapy is efficacious: a further analysis of the Dutch Bone Metastasis Study controlling for the influence of retreatment. International journal of radiation oncology biology, physics 2004, 59(2):528-537.

29. Nelson JW, Yoo DS, Sampson JH, Isaacs RE, Larrier NA, Marks LB, Yin FF, Wu QJ, Wang Z, Kirkpatrick JP: Stereotactic body radiotherapy for lesions of the spine and paraspinal regions. International journal of radiation oncology, biology, physics 2009, 73(5):1369-1375.

30. Sahgal A, Ames C, Chou D, Ma L, Huang K, Xu W, Chin C, Weinberg V, Chuang $C$, Weinstein $P$, et al: Stereotactic body radiotherapy is effective salvage therapy for patients with prior radiation of spinal metastases. International journal of radiation oncology, biology, physics 2009, 74(3):723-731.

31. Lovelock DM, Zhang Z, Jackson A, Keam J, Bekelman J, Bilsky M, Lis E, Yamada Y: Correlation of local failure with measures of dose insufficiency in the high-dose single-fraction treatment of bony metastases. International journal of radiation oncology, biology, physics 2010, 77(4):1282-1287.

32. Bilsky MH, Laufer I, Fourney DR, Groff M, Schmidt MH, Varga PP, Vrionis FD, Yamada Y, Gerszten PC, Kuklo TR: Reliability analysis of the epidural spinal cord compression scale. J Neurosurg Spine 2010, 13(3):324-328.

33. Partridge M, Ramos M, Sardaro A, Brada M: Dose escalation for non-small cell lung cancer: analysis and modelling of published literature. Radiother Oncol 2011, 99(1):6-11.

34. Damast S, Wright J, Bilsky M, Hsu M, Zhang Z, Lovelock M, Cox B, Zatcky J, Yamada Y: Impact of Dose on Local Failure Rates after Image-Guided Reirradiation of Recurrent Paraspinal Metastases. International journal of radiation oncology, biology, physics 2010.

35. Kirkpatrick JP, Meyer JJ, Marks LB: The linear-quadratic model is inappropriate to model high dose per fraction effects in radiosurgery. Semin Radiat Oncol 2008, 18(4):240-243.

36. Ryu S, Jin JY, Jin R, Rock J, Ajlouni M, Movsas B, Rosenblum M, Kim JH: Partial volume tolerance of the spinal cord and complications of singledose radiosurgery. Cancer 2007, 109(3):628-636.

37. Gibbs IC, Patil C, Gerszten PC, Adler JR, Burton SA: Delayed radiationinduced myelopathy after spinal radiosurgery. Neurosurgery 2009, 64(2 Suppl):A67-72.

38. Sahgal A, Ma L, Gibbs I, Gerszten PC, Ryu S, Soltys S, Weinberg V, Wong S, Chang E, Fowler J, et al: Spinal cord tolerance for stereotactic body radiotherapy. International journal of radiation oncology, biology, physics 2010, 77(2):548-553.

39. Schultheiss TE, Kun LE, Ang KK, Stephens LC: Radiation response of the central nervous system. Int J Radiat Oncol Biol Phys 1995, 31(5):1093-1112.
40. Daly ME, Luxton G, Choi CY, Gibbs IC, Chang SD, Adler JR, Soltys SG: Normal Tissue Complication Probability Estimation by the LymanKutcher-Burman Method Does Not Accurately Predict Spinal Cord Tolerance to Stereotactic Radiosurgery. International journal of radiation oncology, biology, physics 2011.

\section{doi:10.1186/1748-717X-6-172}

Cite this article as: Guckenberger et al:: Clinical practice of imageguided spine radiosurgery - results from an international research consortium. Radiation Oncology 2011 6:172.

\section{Submit your next manuscript to BioMed Central and take full advantage of:}

- Convenient online submission

- Thorough peer review

- No space constraints or color figure charges

- Immediate publication on acceptance

- Inclusion in PubMed, CAS, Scopus and Google Scholar

- Research which is freely available for redistribution 